Geophysies (Palaeomagnetic Dating of Hydrothermal Mineralization, Spissko-gemerské Rudohorie Area, Czechoslovakia. By Václav Hanuš and Miroslav Krs. Rozpravy Ceskoslovenské akademie vĕd, Rada MPV 14. Pp. 88+ 4 pl. 1963. Price 10 crowns; 10s.). The investigation has involved a comparison between (1) the direction of remanent magnetism found in a collection of 835 oriented samples from hæmatite-bearing ore deposits in the Western Carpathians; and (2) geochronological curves of polar wandering established from magnetic determinations on stratigraphically defined rocks. The ore deposits occur as veins and replacements in sediments of Permian, Triassic and Carboniferous age; and according to the palæomagnetic data the time of emplacement of the mineralization ranged from Upper Jurassic to Palæogene. Although it is uncertain whether this range reflects a rather long period of ore deposition or whether it results from yet inadequate charts of polar wandering, the firm deduction can be made that the mineralization is of Alpine and not of Variscan age, so terminating a controversy which has lasted for more than half a century. It seems likely that this palæomagnetic method will prove useful in attempts to arrive at the age of some relatively young ore deposits in other parts of the world.

\section{The East Midlands Geological Society}

THe East Midlands Geological Society was formed at a meeting held at Nottingham on February 1. The Society hopes to attract members particularly from an area including Derby, Matlock, Mansfield, Newark, Lincoln, Grantham and Loughborough, hence the reason for it being called the East Midlands Geological Society. Anyone interested in the activities of this Society should contaot the secretary, R. W. Morrell, 443 Meadow Lane, Nottingham. The Society will hold regular meetings in the form of lectures, excursions, visits, exhibitions, discussions and many other activities of a geological character. It is hoped to publish a journal of records, activities and original papers dealing with the region and perhaps further afield. Editorial queries should be addressed to the editor, Dr. W. A. S. Sarjeant, Department of Geology, University of Nottingham, Nottingham. The first president of the Society is P. C. Stevenson.

\section{Gordon Research Conferences, 1964}

THE Gordon Research Conferences, which are designed to stimulate research in universities, research foundations and industrial laboratories, will be held this year at five locations in New Hampshire during June 15-September 4. Fifty five-day conferences will be held, covering a wide range of topics in the physical and biological sciences. The purpose of the conferences is to discuss the latest scientific developments, analyse their significance, and provoke suggestions for further research. Residence and registration oharges for each conference will amount to 115 dollars. Further information and forms of application can be obtained from Dr. W. George Parks, director, Gordon Research Conferences, University of Rhode Island, Kingston, Rhode Island.

\section{G. J. Mendel Memorial Symposium}

THE year 1965 marks the hundredth anniversary of the publication of Gregor Mendel's Versuche über Pflanzenhybriden, which, along with his subsequent communieation on hybrids in Hieracia, forms the foundation stone to most modern-day theories of heredity. The Czeehoslovak Academy of Sciences is organizing a Memorial Symposium which will be held in Brno in the beginning of August 1965. It is hoped that the programme will include a symposium on the mutational process. The chairman of the organizing committee is Prof. B. Nermec; further information can be obtained from the secretary-general of the Symposium Organizing Committee, Dr. Milan Sosna, Na Cvičisti 2, Prague 6.

\section{Announcements}

Sir Charles Goodeve, director of the British Iron and Steel Research Association, has been awarded the Silver Medal of the Operational Research Society, in recognition of "his extensive contribution to the advancement of operational research through the war-time and post-war years".

Dr. A. KELLER, research assistant in charge of polymer research in the Department of Physics at the University of Bristol, has been awarded the third American Physical Society High-Polymer Physics Prize for his contributions to the studies of the growth and properties of polymer crystals, and in particular for his discovery of molecularchain folding. The Prize is sponsored by the Ford Motor Company.

THE Arnold Gerstenberg studentship for $1 y 65$ is open to students in the University of Cambridge who, going into residence not earlier than 1959, have obtained honours in the Natural Sciences Tripos and who wish to pursue a course of philosophical study. The studentship will be awarded for an essay, which must be submitted before May 1, 1965. Further information can be obtained from Mr. Gerd Buchdahl, Whipple Science Museum, Free School Lane, Cambridge.

The first Cosmetic Industry Exhibition will be held at Brighton during April 14-16. Further information can be obtained from Events Promotions, Ltd., 4 Mill Street, Hanover Square, London, W.1.

A Four-Day convention of the Applied Mechanics Group of the Institution of Mechanical Engineers will be held in Newcastle upon Tyne during April 14-17. Further information can be obtained from Mr. H. Umpleby, Institution of Mechanical Engineers, 1 Birdcage Walk, London, S.W.1.

A SYMPosIUM on "Nutrition of Micro-organisms", arranged by the Nutrition Society (Scottish Group), will be held at the Rowett Research Institute, Bucksburn, Aberdeen, on April 11. Further information can be obtained from Dr. D. G. Armstrong, Department of Agricultural Biochemistry, University of Newcastle upon Tyne.

THE following meetings, sponsored by the U.S. Air Force, have been arranged for 1964: seminar on "Nonlinear Partial Differential Equations in Mathematical Physics" (New York, April 20-23); fourth conference on "Rare-earth Research" (Phoenix, Arizona, April 22-25); symposium on "Applied Mathematics and Mechanics" in honour of Theodore von Karman (Washington, D.C., May 11-14); fourteenth MRI series symposium on "Quasi Optics" (New York, June 8-10); international conference on "Physics and Chemistry" (Providence, Rhode Island, June 21-26); international biophysics meeting (Paris, June 22-27); international conference on "Photosensitization in Solids" (Chicago, June 22-24); symposium on "Quantitative Biology" (Cold Spring Harbor, N.Y., June); "Concentrated Vortex Motions in Fluids" (Ann Harbor, Michigan, July 6-11); summer research institute on "Algebraic Geometry" (Woods Hole, Mass., July 6-31); fourth international symposium on "Rarefied Gas Dynamics" (Toronto, July 14-17); international congress on "Semiconductor Physies" (Paris, July 20-24); twenty-fifth International Astronomical Union sym. posium ('Thessaloniki, Greece, August 17-22); conference on "High-altitude Plastic Balloons" (Boston, September or October); second Bagnères conference on "Lunar Topology" (Bagnères-de-Bigorre and Pic-du Midi Observatory, France, summer). Further information can be obtained from the Office of Aerospace Research, 4th and Independence Avenue, S.W., Washington, 25, D.C. 